\title{
Mitral valve gradient after repair of degenerative regurgitation with restrictive annuloplasty: A conundrum of knowledge
}

\author{
José M. Bernal, MD, PhD, ${ }^{a}$ and Carlos A. Mestres, MD, PhD, FETCS ${ }^{b}$ \\ From the ${ }^{\mathrm{a}}$ Department of Cardiovascular Surgery, University of Cantabria, Santander, Spain, and the ${ }^{\mathrm{b}}$ Department \\ of Thoracic and Cardiovascular Surgery, Heart \& Vascular Institute, Cleveland Clinic Abu Dhabi, Abu Dhabi, \\ United Arab Emirates. \\ Disclosures: Authors have nothing to disclose with regard to commercial support. \\ Received for publication Oct 10, 2015; accepted for publication Oct 17, 2015. \\ Address for reprints: José M. Bernal, MD, PhD, Department of Cardiovascular Surgery, Universidad de Cantabria \\ Hospital, Universitario Valdecilla E-39008, Santander, Spain (E-mail: bernal@humv.es). \\ J Thorac Cardiovasc Surg 2016;151:110-1 \\ $0022-5223 / \$ 36.00$ \\ Copyright (c) 2016 by The American Association for Thoracic Surgery \\ http://dx.doi.org/10.1016/j.jtcvs.2015.10.055
}

Very recently, 2 scientific studies published by international and multidisciplinary teams have confirmed that some mutations in the DCHS1 gene on chromosome 11 are responsible for the prolapse of the mitral valve., This is a well-known mitral valve abnormality, and the authors of these studies understand that it is a leading indication for mitral valve surgery because it clinically manifests as mitral regurgitation, which paves the way for heart failure and death. We have known this for quite some time. In the westernized environment, mitral valve prolapse overtakes rheumatic heart disease as an indication for operative treatment of the mitral valve. ${ }^{3}$ These studies are contemporary with the substantial experience published in this issue of The Journal of Thoracic and Cardiovascular Surgery by Murashita and colleagues, ${ }^{4}$ a series including 1147 patients operated on during a period of 10 years. This study focuses on the assessment of the postoperative evolution of residual mitral valve gradient after repair surgery with a number of techniques. An unmeasured 63-mm flexible band annuloplasty was largely used after triangular posterior leaflet resection and plication. The posterior leaflet, as expected, was the target in $67 \%$ of the cases. The results of this approach were optimal for these patients with degenerative mitral regurgitation. The mean gradient of $3.1 \mathrm{~mm}$ $\mathrm{Hg}$ measured in the operating room increased at discharge to $3.8 \mathrm{~mm} \mathrm{Hg}$, but after a mean follow-up of $1.6 \pm 2.4$ years decreased to $3.5 \mathrm{~mm} \mathrm{Hg}(P<.001)$.

Some aspects of the contribution of Murashita and colleagues ${ }^{4}$ are of strong interest to the Journal's readership. To start with, there is no doubt that, not only for what Murashita and colleagues ${ }^{4}$ describe but for other robust published data, ${ }^{5}$ mitral valve repair is the criterion standard for the treatment of degenerative disease. This is a fact. It is important to acknowledge that, according to the philosopher Jean François Revel at the end of the 20th century, knowledge does not need usefulness. ${ }^{6}$ This means that the value of knowledge is independent of how

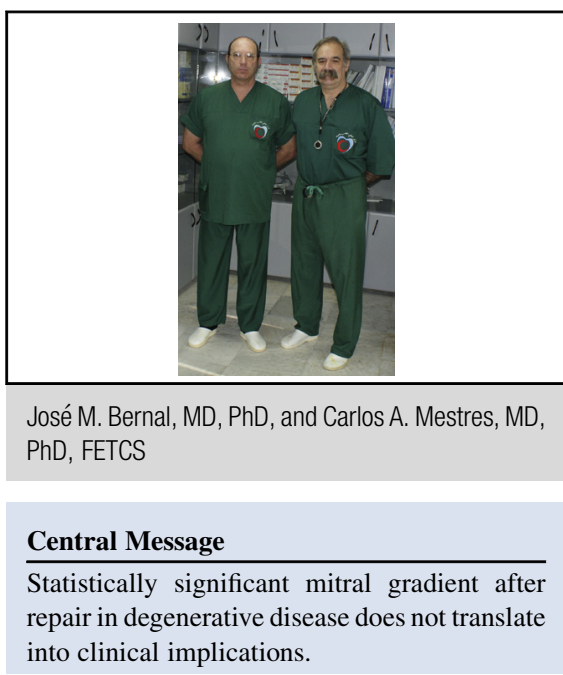

See Article page 106.

See Editorial page 7 practical or productive it could be. The question therefore arises as to how useful is the information produced by Murashita and colleagues. ${ }^{4}$ We observe that the objective of their study was the analysis of mitral transvalvular gradient after repair surgery in degenerative disease. It is well known that the main driver for failure of this corrective surgery is the persistence or recurrence of mitral regurgitation, whereas midterm or long-term reinterventions for mitral stenosis are uncommon. In the experience of Murashita and colleagues, ${ }^{4} 91.4 \%$ of reinterventions were indicated for mitral regurgitation and only $5.7 \%$ for stenosis. On the other hand, the variability in mean mitral gradient, measured with different echocardiographic techniques, shows that the gradient ranged from $2.7 \mathrm{~mm} \mathrm{Hg}$ to $3.8 \mathrm{~mm} \mathrm{Hg}$ at the time of intraoperative assessment and between $3.3 \mathrm{~mm} \mathrm{Hg}$ and $4.3 \mathrm{~mm} \mathrm{Hg}$ at studies done during the follow-up. The mean value of variability was $0.4 \mathrm{~mm} \mathrm{Hg}$. Could this have some clinical impact, other than the statistical significance? According to Jean François Revel, the answer is that it is lacking importance.

Murashita and colleagues ${ }^{4}$ have to be commended for a well-organized and substantial piece of information produced with the understanding that regurgitation is what counts. It is also clear from their information. 


\section{References}

1. Durst R, Sauls K, Peal DS, deVlaming A, Toomer K, Leyne M, et al. Mutation in DCHSI causes mitral valve prolapse. Nature. 2015;525:109-13.

2. Dina C, Bouatia-Naji N, Tucker N, Delling FN, Toomer K, Durst R, et al; Leducq Transatlantic MITRAL Network. Genetic association analyses highlight biological pathways underlying mitral valve prolapse. Nat Genet. 2015;47:1206-11.

3. Bernal JM, Pontón A, Diaz B, Llorca J, García I, Sarralde A, et al. Combined mitral and tricuspid valve repair in rheumatic disease: fewer reoperations with prosthetic ring annuloplasty. Circulation. 2010;121:1934-40.

4. Murashita T, Greason KL, Suri RM, Daly RC, Joyce LD, Stulak JM, et al. Mitral valve gradient after valve repair of degenerative regurgitation with restrictive annuloplasty. J Thorac Cardiovasc Surg. 2016;151: 106-9.

5. David TE, Armstrong S, McCrindle BW, Manlhiot C. Late outcomes of mitral valve repair for mitral regurgitation due to degenerative disease. Circulation. 2013; 127:1485-92.

6. Revel JF. The flight from truth: the reign of deceit in the age of information. New York: Random House; 1991. 